\title{
Insect succession on carrion in Fars Province, southwestern Iran
}

\author{
Davood Keshavarzi ${ }^{1,2^{*}}$, Mohammad Ali Zaimy ${ }^{3}$, Mustapha Ahmed Yusuf ${ }^{4}$, Marzieh Shahriarinamadi ${ }^{2}$ and \\ Sogol Parkhideh ${ }^{1}$
}

\begin{abstract}
Background: The entomofauna found on animal carrion, which is used as vertebrate model, can help in the estimation of postmortem interval (PMI). The aim of this study was to determine the succession pattern of insects on carrion in outdoor and indoor habitats in Fars Province, southwestern Iran.

Results: A total of 19 species from nine families were collected. Chrysomya albiceps and Musca domestica were the first species to visit the outdoor carrion while only Musca domestica was seen on the indoor carrion. Sarcophaga crassipalpis, Lucillia sericata, and Histeridae species were observed exclusively on the indoor carrion while Dermestes maculatus, Piophila casei, and some hymenopteran species were the most dominant species seen on the outdoor carrion. Vespula germanica and Vespa orientalis fed on both outdoor and indoor habitats.
\end{abstract}

Conclusion: Insects' succession pattern was found to differ between the two respective habitats. This is really important and could be used in medicolegal cases to estimate the PMI.

Keywords: Forensic entomology, Outdoor, Indoor, Carrion, Iran

\section{Background}

Insects play an important role in forensic medicine, where they are used to estimate the post mortem interval (PMI), which is the time interval between death and recovery of the corpse (Catts and Goff 1992). Diptera (flies) and Coleoptera (beetles) are the two most important insect orders used in the field of forensic entomology, both orders colonize carrion in a predictable succession pattern; dipteran species are found mainly in the early stage of decomposition, while beetles are found in the later stages (Gennard 2007). Insects are ectothermic and specifically susceptible to climatic changes. Diversity and succession waves are affected by weather, temperature, relative humidity, body decomposition stage, size, and location of the carrion (Mann et al. 1990; Turchetto and Vanin 2004). Insect succession pattern in an outdoor environment is quite different from that in an indoor environment. Indoor environments prevent the entomofauna from gaining adequate access on the carrion which affect the

\footnotetext{
* Correspondence: keshavarzd25@gmail.com

${ }^{1}$ Legal Medicine Research Center, Legal Medicine Organization, Tehran, Iran

${ }^{2}$ Students' Scientific Research Center, Tehran University of Medical Sciences,

Tehran, Iran

Full list of author information is available at the end of the article
}

decomposition stages (Reibe and Madea 2010; Anderson 2011). It has been proven that many carrion-frequenting insects in indoor environments are synanthropic (Anderson 2011). A number of deaths occur inside homes, and deceased persons are often not discovered for some time. In Iran, five out of the 15 human cadavers studied were found inside houses (Moemenbellah-Fard et al. 2018). Various animal models (domestic pig, rabbit, domestic cat, and rat) have been used for successional studies (Early and Goff 1986; Tomberlin and Adler 1998; Anderson 2011; Zeariya et al. 2015). Domestic pig is considered to be the most suitable human model for forensic studies (Catts and Goff 1992).

The aim of this study was to determine the insect succession pattern on a rat carrion in both outdoor and indoor habitats.

\section{Materials and methods \\ Study sites}

The study was conducted in the city of Mamassani, Fars Province, Southwest of Iran (30006' 51' ' N 51031' 18" E). The city is located $150 \mathrm{~km}$ north of Shiraz (the capital of Fars Province) with more than 117,000 inhabitants, and characterized by local steppe climate with average annual 
rainfall of $261 \mathrm{~mm}$. Two habitats, $10 \mathrm{~km}$ apart, were chosen for sampling. The first is an outdoor peri-urban habitat with abundant oak trees and wheat fields, and the second is an indoor urban habitat, with open door and window that regulated the access of insects.

\section{Study time}

The study was conducted in autumn between September and October, 2017.

\section{Carrion}

Permission to conduct this study was granted by the Ethical Committee of Tehran University of Medical Science. For each habitat, two albino rats (180-185 g) were killed by chloroform and placed in a separate metal cage $(70 \times 40 \times 40 \mathrm{~cm})$ with $1.5 \mathrm{~cm}$ mesh. Insect's samples were saved during the fresh, bloated, decay, and dry stages of decomposition.

\section{Examination procedure and taxonomic identification}

During the study period, samples of insects were collected three times daily (09:00, 16:00, and 22:00 h). Adult flies were collected using insect nets, while adult beetles and larvae were collected using forceps and cotton swabs. For morphological identification, the larvae were divided into two; some were immersed into hot water for $5 \mathrm{~min}$ to die and then stored in $70 \%$ alcohol, while the remaining larvae were transferred to the laboratory for rearing to adult emergence. Valid taxonomic keys were used for the identification of the samples (Halstead 1963; Bolton 1994; Velásquez et al. 2010; Abbasi 2012; Akbarzadeh et al. 2015; Grzywacz et al. 2017). Jaccard index was used to assess similarity and dissimilarity ("1" $=$ total similarity and " 0 " = dissimilarity) between species in each condition. Shannon diversity index $\left(H^{\prime}=-[\Sigma(p i\right.$ $\ln p i)]$, where $p i=n i / N$ [ni is number of specimens of taxon $i]$ ) was used to characterize species diversity in each stage of decomposition (Shannon and Weaver 1949). Data were analyzed using Paleontological Statistics Software Package (PAST) software version 3.14.

\section{Results}

\section{Outdoor habitat}

A total of 1288 specimens belonging to three orders, eight families, nine genera, and 11 species were collected. The dominant families were Calliphoridae (44.1\%), Sarcophagidae (26.5\%), Vespidae (10.5\%), Muscidae $(9.8 \%)$, Formicidae (4.1\%), Fannidae (2.9\%), Dermestidae (1.2\%), and Piophilidae (0.9\%) respectively. Some species were only found in their adult stages (Fannia canicularis) while others were found both in adult and larval stages.

During the first stage of decomposition (fresh stage), Chrysomya albiceps and Musca domestica were the first visitors seen within $2 \mathrm{~h}$. Vespula orientalis was found on day 4, while Vespula germanica was found on day 2 to 4. The blowfly $\mathrm{Ch}$. albiceps was the dominant species during this stage and was collected together with $M$. domestica and Sarcophaga africa. During this stage of the decomposition, $V$. orientalis, a scavenger species was found to attack the dipterans during the daytime. Among the most abundant dipteran species, Ch. albiceps was more active during the night; also, it laid eggs during the fresh stage. The blot stage possessed the highest number of specimens (47.9\%), where the dominant species were Ch. albiceps (26.2\%), Calliphora vicina (23.1\%), and S. africa 22.3\% (Fig. 1). In the third stage of decomposition, the decay stage, precipitation was observed. The activity of some species such as C. vicina did not decrease while significant decrease was seen in the activity of other insect species. During the decay stage, the predominant species were Ch. albiceps (25.9\%) and S. africa (22.4\%). Adults of the beetle Dermestes maculatus were under the carcasses and beneath the soil at a radius of 1-1.5 $\mathrm{m}$ at night. The hymenoptera species $V e$ germanica and $V$. orientalis were captured mainly during the decay stage (Fig. 1). Diversity analysis indicated higher species richness and species diversity in the decay stage (Fig. 2). During the last stage of decomposition, dry stage, Messor spp. (28.3\%) was the dominant species and Piophila casei was found exclusively in this stage. The adults of $P$. casei are small and very active, making their collection difficult. They were found near the carrions under the shadow of the rocks. This species is mostly active during the daytime, when the hornets are absent. The succession of species on the carrion is

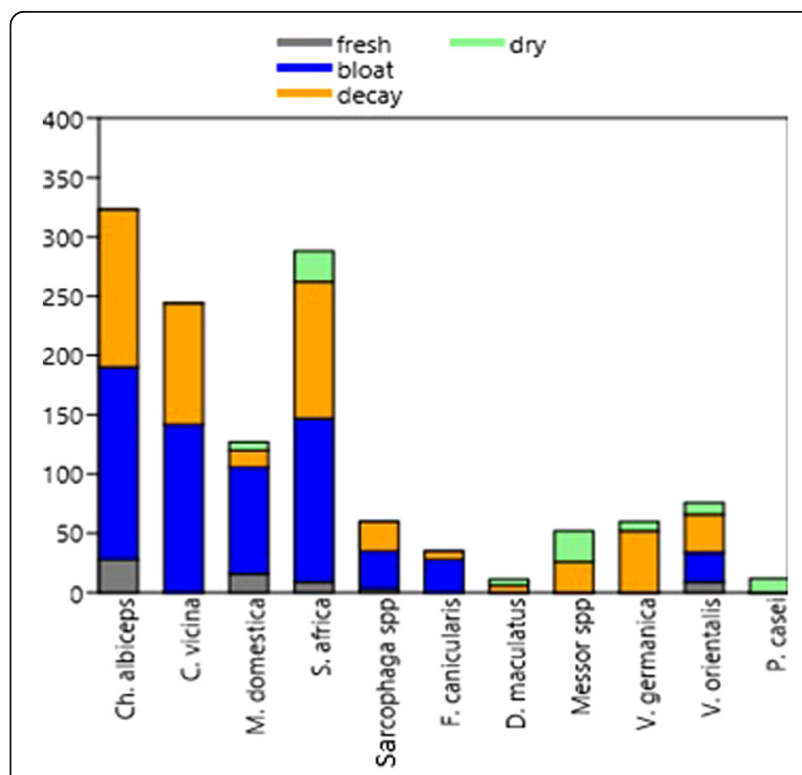

Fig. 1 Number of insect species collected in the outdoor habitat during different stages of decomposition 


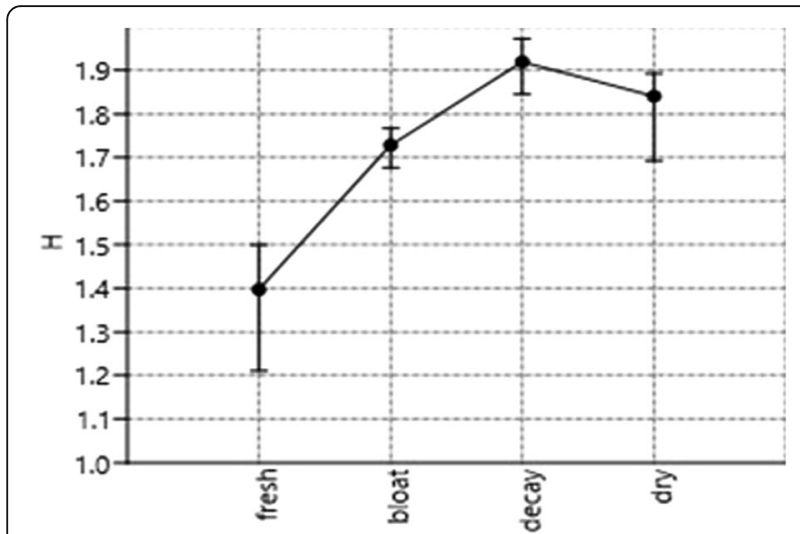

Fig. 2 Shannon index value for each cadaveric decomposition stage in the outdoor habitat

shown in Table 1. Co-phenetic correlation of insect species in different stages of decomposition based on Jaccard's index is provided in (Fig. 3).

\section{Indoor habitat}

A total of 781 specimens belonging to two orders, five families, seven genera, and eight species were collected. The dominant families are Calliphoridae (53.2\%), Sarcophagidae (28.8\%), Muscidae (12.2\%), Fannidae (3.6\%), and Histeridae (2.2\%). During the fresh stage of decomposition, the first visitors were seen within $24 \mathrm{~h}$. By day 2 of the decomposition, few numbers of adult flies were found, and the eggs of Lucillia sericata were also found on the carrion. The house fly $M$. domestica was the dominant species in the fresh stage. During the bloat stage, the highest number of insect species were collected (44.7\%) and Sarcophaga crassipalpis was the most abundant species $32.2 \%$ (Fig. 4). Diversity analysis indicates high species richness and species diversity in the bloat stage (Fig. 5). During the decay stage, the activity of $M$. domestica ceased completely and the larvae of

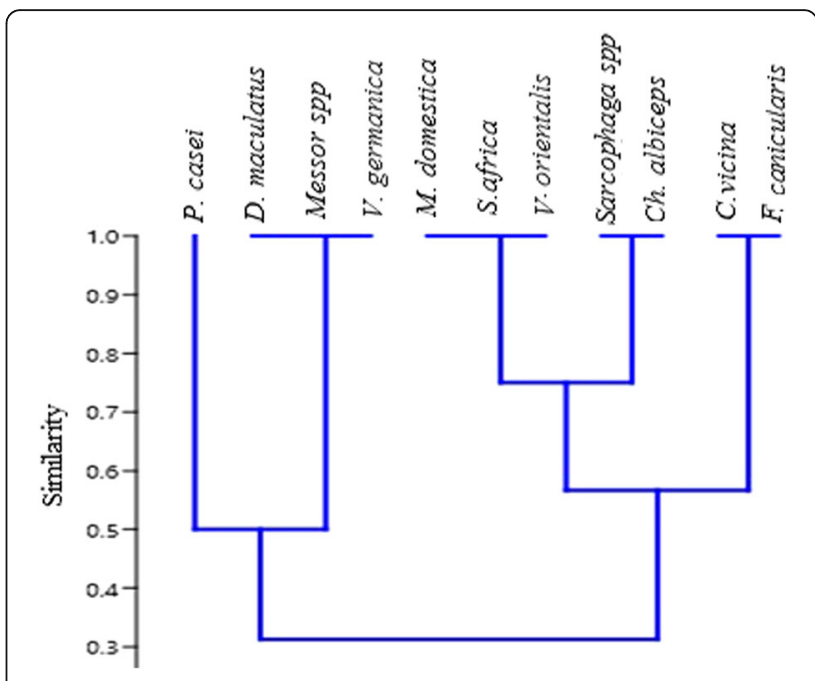

Fig. 3 Cluster analysis based on Jaccard's distance in the outdoor habitat; cophenetic correlation $=0.89$

dipterans left the carrion. A large number of pupae were found at the end of the decay stage. During the dry stage, the activities of the insects decreased drastically and $M$. domestica was found to be the most dominant species (43.3\%). Hister spp. species and D. maculatus were found exclusively in the dry stage. The succession of insect species on the carrion is shown in Table 2 . Co-phenetic correlation for those species in different stages of decomposition based on Jaccard's index is also provided (Fig. 6).

\section{Discussion}

In this study, the outdoor carrion was found to decompose faster than the indoor carrion. Flies were seen mainly during the early stage of decomposition while beetles were seen at the later stage. The house fly $M$. domestica was a primary colonizer in the indoor habitat, while Ch. albiceps was in addition seen in the outdoor

Table 1 Insect succession in the outdoor habitat Mamasani city, Iran

\begin{tabular}{|c|c|c|c|c|c|}
\hline Family & Species & Fresh (0-1) & Bloat (2-4) & Decay (5-16) & Dry (17-32) \\
\hline \multirow[t]{2}{*}{ Calliphoridae } & Chrysomya albiceps & $0-1$ & $2-4$ & $5-8,10-14$ & \\
\hline & Calliphora vicina & & $3-4$ & $5-12,15$ & \\
\hline Muscidae & Musca domestica & $0-1$ & $2-4$ & & $18,19,22,30-32$ \\
\hline \multirow[t]{2}{*}{ Sarcophagidae } & Sarcophaga africa & 1 & $2-4$ & $5-8,13-16$ & 17 \\
\hline & Sarcophaga spp. & 1 & $3-4$ & $5-11$ & \\
\hline Fannidae & Fannia canicularis & & $3-4$ & $5-8$ & \\
\hline Dermestidae & Dermestes maculatus & & & 16 & $17,20-21,29$ \\
\hline Formicidae & Messor spp. & & & 15,16 & $17-23,28-32$ \\
\hline \multirow[t]{2}{*}{ Vespidae } & Vespula germanica & & $2-4$ & $5-9,16$ & $26,28,29$ \\
\hline & Vespa orientalis & 0 & 4 & $5-7,12-14$ & $19-32$ \\
\hline Piophilidae & Piophila casei & & & & $17,25-29$ \\
\hline
\end{tabular}




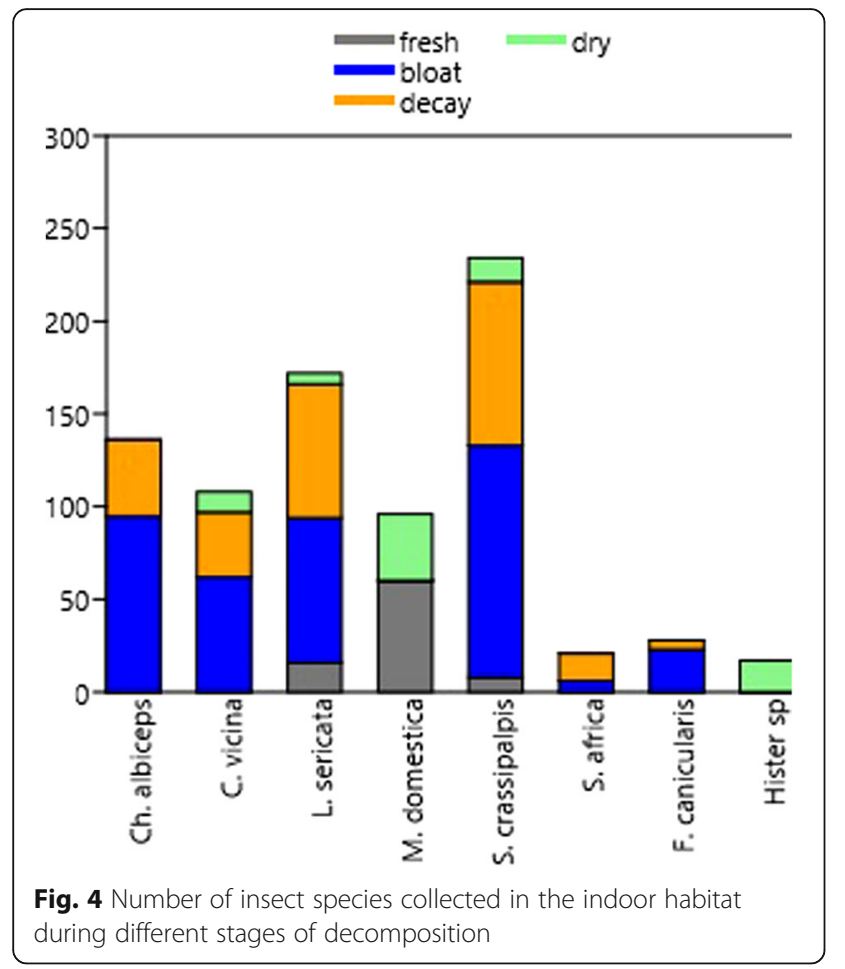

habitat. This finding is similar to the previous reports from Brazil and Argentina (Carvalho and Linhares 2001; Battán Horenstein et al. 2010). The cheese fly P. casei was seen exclusively in the dry stage in the outdoor habitat; this species could be used as a bio-indicator in forensic medicine. However, studies from USA and Thailand on arthropod succession pattern showed that P. casei is active in decay stage between days 5 and 11 (Early and Goff 1986; Vitta et al. 2007). Contrary to the present findings, a study in central Argentina showed that this species appeared in spring on the carcasses

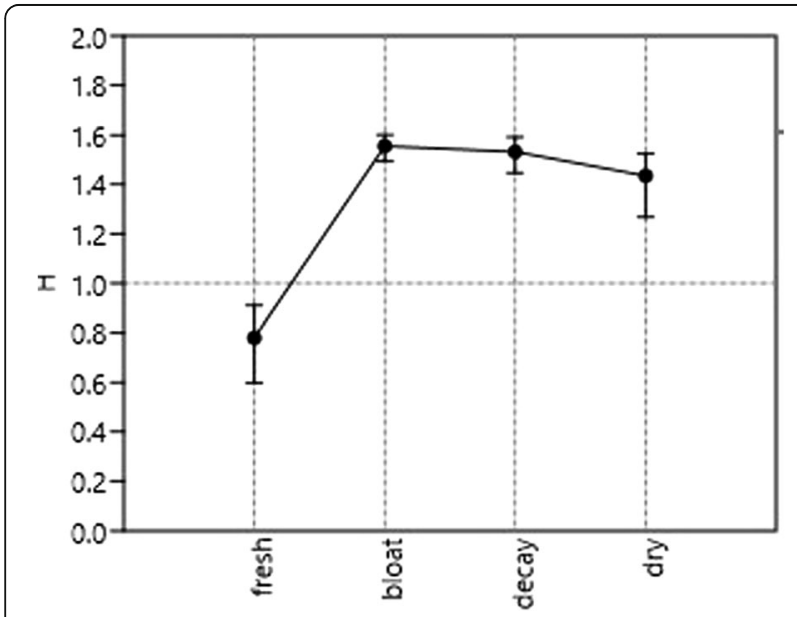

Fig. 5 Shannon index value for each cadaveric decomposition stage in the indoor habitat
Table $\mathbf{2}$ Insect succession in the indoor habitat Mamasani city, Iran

\begin{tabular}{|c|c|c|c|c|c|}
\hline Family & Species & $\begin{array}{l}\text { Fresh } \\
(0-2) \\
\end{array}$ & $\begin{array}{l}\text { Bloat } \\
(3-5)\end{array}$ & $\begin{array}{l}\text { Decay (6- } \\
\text { 19) }\end{array}$ & $\begin{array}{l}\text { Dry } \\
(20-38)\end{array}$ \\
\hline \multirow[t]{3}{*}{ Calliphoridae } & $\begin{array}{l}\text { Lucilia } \\
\text { sericata }\end{array}$ & 2 & $4-5$ & $6-15,19$ & 20,23 \\
\hline & $\begin{array}{l}\text { Chrysomya } \\
\text { albiceps }\end{array}$ & & 5 & $6-10,13$ & \\
\hline & $\begin{array}{l}\text { Calliphora } \\
\text { vicina }\end{array}$ & & $3-5$ & $\begin{array}{l}8-10,18- \\
19\end{array}$ & $20,23,26$ \\
\hline Muscidae & $\begin{array}{l}\text { Musca } \\
\text { domestica }\end{array}$ & 1 & & & $32-38$ \\
\hline \multirow[t]{2}{*}{ Sarcophagidae } & $\begin{array}{l}\text { Sarcophaga } \\
\text { crassipalpis }\end{array}$ & 2 & $3-5$ & $6-16$ & $\begin{array}{l}25,28,29 \\
32\end{array}$ \\
\hline & $\begin{array}{l}\text { Sarcophaga } \\
\text { africa }\end{array}$ & & 5 & 11,15 & \\
\hline Fannidae & $\begin{array}{l}\text { Fannia } \\
\text { canicularis }\end{array}$ & & $4-5$ & 8 & \\
\hline Histeridae & Hister sp. & & & & $\begin{array}{l}26,29 \\
30-33\end{array}$ \\
\hline
\end{tabular}

during the fresh stage of decomposition (Battán Horenstein et al. 2010). Hence, from the studies above, it can be concluded that this species has different succession pattern in different regions.

In the current study, it has also been found that flesh flies colonize the outdoor carcasses later than muscid and calliphorid flies. This pattern is reported by other researchers from different regions (Early and Goff 1986; Vitta et al. 2007). The flies S. crassipalpis and $L$. sericata were observed exclusively on the indoor carcasses. These flies have been seen on indoor carrions from different regions (Goff 1991; Anderson 2011; Baz et al. 2015). The flesh fly $S$. africa and the blowfly C. vicina were observed on both outdoor and indoor carcasses, but they were more abundant in the outdoor. The blowfly $C$.

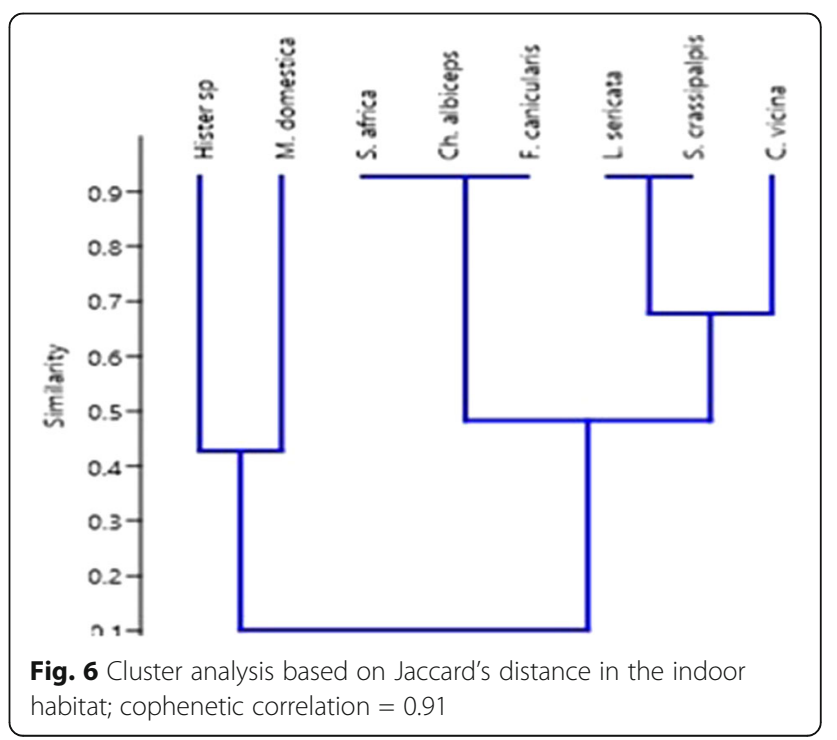


vicina have been reported as an important colonizer on both outdoor and indoor carcasses from Canada. This species is a later arriver on indoor carcasses, but laid eggs immediately on the outside remains (Anderson 2011). The flesh fly S. africa (Sarcophaga haemorrhoidalis) have been sampled from indoor and outdoor carrions in the early stage of decomposition (Ndueze et al. 2013; Keshavarzi et al. 2015). The flies S. africa and C. vicina were recorded from both indoor and outdoor human corpses from different regions (Introna et al. 1998; Moemenbellah-Fard et al. 2018). Dermestid beetles have been previously documented as common species associated with carcass during later stages of decomposition, because they prefer to feed on dried tissues (Miller et al. 1994). D. maculatus was mainly found on the outdoor carcasses during the later stages of decomposition. A review of 81 human corpses in France showed that this species developed only on human cadavers in outdoor locations (Charabidze et al. 2014). Our finding is similar to the above study (Early and Goff 1986; Vitta et al. 2007). Hister sp. was found on the indoor carcass in the dry stage. This species have been reported on indoor carrions in the later stage of decomposition (Anderson 2011). According to a study from Egypt, Hister sp. was discovered during the decay and advanced decay stages of indoor and outdoor carrions (Zeariya et al. 2015). Histerid beetles and hymenopteran species preyed on fly larvae (Early and Goff 1986; Martinez et al. 2007). So, they can be seen at every stage of decomposition. According to a study on rat carrion from southern Iran, decomposition time for carrion lasted for 38 days and Saprinus planiusculus (a histerid beetle) was collected between fresh and post decay stages (Fakoorziba et al. 2017).

In this study, we found that hymenopteran species fed on both carcasses and larvae in the outdoor environment. This finding is similar to a study conducted in Austria, where they reported Ve. germanica as a calliphorid predator (Grassberger and Frank 2004). Therefore, predation activity of some species may change the succession patterns.

\section{Conclusion}

The current study provides basic information in the field of forensic entomology and we conclude that insect composition and succession patterns are different between outdoor and indoor habitats. Furthermore, this study reveals that insects, especially hymenoptera species, mediated the decomposition process of carrion.

\section{Abbreviations}

C: Calliphora; Ch: Chrysomya; D: Dermestes; L: Lucilia; M: Musca; P: Piophila; S: Sarcophaga; V: Vespa; Ve: Vespula
Acknowledgements

We would like to thank to Mr. Izedi for identification of Hymenoptera.

\section{Funding}

This study received financial support from Tehran University Medical Sciences, Legal Medicine Research Center, Legal Medicine Organization, Tehran, Iran

\section{Availability of data and materials}

They are available at school of public health, Tehran University of Medical Science.

\section{Authors' contributions}

KD and SP planned the entomological sampling and performed the species identification. ZM wrote the manuscript in collaboration with MS and MAY.

All authors read and approved the final manuscript.

Authors' information

Not applicable.

\section{Ethics approval and consent to participate}

Necessary ethical approval was obtained from School of Public Health, Tehran University of Medical Sciences Ethics Committee, code number: IR.TUMS.VCR.REC.1396.3607.

Consent for publication

Not applicable.

\section{Competing interests}

The authors declare that they have no competing interests.

\section{Publisher's Note}

Springer Nature remains neutral with regard to jurisdictional claims in published maps and institutional affiliations.

\section{Author details}

${ }^{1}$ Legal Medicine Research Center, Legal Medicine Organization, Tehran, Iran. 'Students' Scientific Research Center, Tehran University of Medical Sciences, Tehran, Iran. ${ }^{3}$ Department of Medical Genetics, School of Medicine, Ilam University of Medical Sciences, Ilam, Iran. ${ }^{4}$ Department of Medical Entomology and Vector Control, School of Public Health, International Campus, Tehran University of Medical Sciences, Tehran, Iran.

Received: 23 March 2018 Accepted: 15 April 2019

Published online: 01 May 2019

\section{References}

Abbasi R (2012) On the distribution and taxonomy of vespine wasps of Iran (Hymenoptera: Vespidae: Vespinae). Acta Mus Morav Sci Biol 97:69-86 Akbarzadeh K, Wallman JF, Sulakova H, Szpila K (2015) Species identification of Middle Eastern blowflies (Diptera: Calliphoridae) of forensic importance. Parasitol Res 114:1463-1472

Anderson GS (2011) Comparison of decomposition rates and faunal colonization of carrion in indoor and outdoor environments. J Forensic Sci 56:136-142

Battán Horenstein M, Xavier Linhares A, Rosso de Ferradas B, García DD (2010) Decomposition and dipteran succession in pig carrion in central Argentina: ecological aspects and their importance in forensic science. Med Vet Entomol 24:16-25

Baz A, Botías C, Martín-Vega D, Cifrián B, Díaz-Aranda LM (2015) Preliminary data on carrion insects in urban (indoor and outdoor) and periurban environments in central Spain. Forensic Sci Int 248:41-47

Bolton B (1994) Identification guide to the ant genera of the world. Harvard University Press, Cambridge

Carvalho LML, Linhares AX (2001) Seasonality of insect succession and pig carcass decomposition in a natural forest area in southeastern Brazil. J Forensic Sci 46:604-608

Catts EP, Goff ML (1992) Forensic entomology in criminal investigations. Annu Rev Entomol 37:253-272

Charabidze D, Colard T, Vincent B, Pasquerault T, Hedouin V (2014) Involvement of larder beetles (Coleoptera: Dermestidae) on human cadavers: a review of 81 forensic cases. Int J Legal Med 128:1021-1030 
Early M, Goff ML (1986) Arthropod succession patterns in exposed carrion on the island of O'Ahu, Hawaiian islands, USA. J Med Entomol 23:520-531

Fakoorziba MR, Assareh M, Keshavarzi D, Soltani A, Moemenbellah-Fard MD, Zarenezhad M (2017) Saprinus planiusculus (Motschulsky ,1849) (Coleoptera: Histeridae), a beetle species of forensic importance in Khuzetan Province, Iran. Egypt J Forensic Sci 7:11

Gennard DE (2007) Forensic entomology- an introduction. Wiley, England

Goff ML (1991) Comparison of insect species associated with decomposing remains recovered inside dwellings and outdoors on the island of Oahu, Hawaii. J Forensic Sci 36:748-753

Grassberger M, Frank C (2004) Initial study of arthropod succession on pig carrion in a central European urban habitat. J Med Entomol 41:511-523

Grzywacz A, Hall MJ, Pape T, Szpila K (2017) Muscidae (Diptera) of forensic importance-an identification key to third instar larvae of the western Palaearctic region and a catalogue of the muscid carrion community. Int J Legal Med 131:855-866

Halstead D (1963) Handbooks for the identification of British insects. R Entomol Soc 4:10-12

Introna F, Campobasso CP, Di Fazio A (1998) Three case studies in forensic entomology from southern Italy. J Forensic Sci 43:210-214

Keshavarzi D, Fereidooni M, Assareh M, Nasiri Z (2015) A checklist of forensic important flies (Insecta: Diptera) associated with indoor rat carrion in Iran. J Entomol Zool Stud 3:140-142

Mann R, Bass W, Meadows L (1990) Time since death and decomposition of the human body: variables and observations in case and experimental field studies. J Forensic Sci 35:103-111

Martinez E, Duque P, Wolff M (2007) Succession pattern of carrion-feeding insects in Paramo, Colombia. Forensic Sci Int 166:182-189

Miller ML, Lord WD, Goff ML, Donnelly B, McDonough ET, Alexis JC (1994) Isolation of amitriptyline and nortriptyline from fly puparia (Phoridae) and beetle exuviae (Dermestidae) associated with mummified human remains. Forensic Sci 39:1305-1313

Moemenbellah-Fard MD, Keshavarzi D, Fereidooni M, Soltani A (2018) First survey of forensically important insects from human corpses in Shiraz, Iran. J Forensic Legal Med 54:62-68

Ndueze OU, Okiwelu SN, Umeozor OC, Noutcha MA (2013) Arthropod succession on wildlife carcasses in lowland rainforest, Rivers state, Nigeria. Euro J Exp Bio 3:106-110

Reibe S, Madea B (2010) How promptly do blowflies colonise fresh carcasses? A study comparing indoor with outdoor locations. Forensic Sci Int 195:52-57

Shannon C, Weaver W (1949) The mathematical theory of communication university of Illinois press Urbana, III, p 144

Tomberlin JK, Adler PH (1998) Seasonal colonization and decomposition of rat carrion in water and on land in an open field in South Carolina. J Med Entomol 35:704-709

Turchetto M, Vanin S (2004) Forensic entomology and climatic change. Forensic Sci Int 146:S207-S209

Velásquez Y, Magaña C, Martínez-Sánchez A, Rojo S (2010) Diptera of forensic importance in the Iberian Peninsula: larval identification key. Med Vet Entomol 24:293-308

Vitta A, Pumidonming W, Tangchaisuriya U, Poodendean C, Nateeworanart S (2007) A preliminary study on insects associated with pig (Sus scrofa) carcasses in Phitsanulok, northern Thailand. Trop Biomed 24:1-5

Zeariya MG, Hammad KM, Fouda MA, Al-Dali AG, Kabadaia MM (2015) Insect succession and decomposition patterns of dog and rabbit carcasses in different habitats. J Entomol Zool Stud 3:473-482

\section{Submit your manuscript to a SpringerOpen ${ }^{\circ}$ journal and benefit from:}

- Convenient online submission

- Rigorous peer review

- Open access: articles freely available online

- High visibility within the field

- Retaining the copyright to your article

Submit your next manuscript at $\boldsymbol{\nabla}$ springeropen.com 